\title{
Limits to competition and regulation in privatised electricity markets
}

\author{
Author: Hulya DAGDEVIREN \\ Business School, University of Hertfordshire \\ College Lane, Hatfield AL10 9AB, Britain \\ E-mail: h.dagdeviren@herts.ac.uk \\ Tel: $+44(0) 1707285469$ \\ Fax: $+44(0) 1707285410$
}

\begin{abstract}
Privatisation of electricity has been extensive both in the developed and the developing world. Failures in various areas have led to the emergence of a new consensus which regards competitive pressures and regulation as crucial for utility privatisations to work. This review paper presents a critical evaluation of this newly found wisdom with reference to the developing economies. The experience in the developed world, especially in the US and the UK, has been used to draw conclusions for the developing economies. Overall, the paper highlights the problems associated with the 'competitive model' both in the developed and developing world and points to the potential instability in private competitive power supply systems. It also examines the degree to which regulation can be a panacea for market failures and structural problems under private provision.
\end{abstract}

Note: An updated version of this paper can be found in Annals of Public and Cooperative Change, 2009, Vol. 80, No 4, pp. 641-664 


\section{Introduction}

Like many other sectors, the electricity industry has been subject to widespread privatisation both in developed and developing countries. In the developing world, the inability of governments to maintain and extend infrastructure during the fiscal crisis in the 1970s and 1980s provided the ideal conditions for arguments against public ownership to gain a stronghold position. Indeed, public electricity utilities in many countries suffered from poor revenue collection, high technical losses, decaying networks and high costs of operation. The coercion associated with policy conditional lending by the IMF and the World Bank under these conditions facilitated the proliferation of privatisation projects. Soon, policy advice was standardised into 'templates' to be used in all countries with diverse conditions (Yi Chong, 2005). For electricity the prescription involved 'vertical unbundling'.

The naïve views of the earlier years have evolved to recognise the complexities associated with privatisation and admitted that there is no universally applicable blueprint for utility sector reforms. The importance of competition and regulation are now emphasized for success after privatisation (Bortolotti and Perotti 2007, Newberry 2004, Estache et al 2005). Similar reflections were also aired by the World Bank over its privatisation drive in infrastructure in a landmark publication on reforming infrastructure (Kessides 2004). A thorough review of the changing views on utility sector reforms since the 1980s and the new wisdom can be found in Bayliss and Fine (2007).

This paper examines the credibility of the new consensus that privatisation of electricity is effective so long as markets are regulated. It draws conclusions for developing countries from the experiences in the developed country markets, especially, the US and the UK. In the next section, it shows that competition remains highly imperfect even in market segments where it has been considered feasible. Investment requirements and associated risks appear significant in impeding the level of competition in the electricity sector. The concept of 'regulatory effectiveness' is discussed in section 3. It is argued that the limited literature on regulatory effectiveness in developing countries failed to open the 'black box'. The dynamic aspects of regulatory effectiveness are ignored and capacity development is perceived as a mechanical process.

\section{Privatisation and competition: The rhetoric and reality in the electricity markets}

Until the 1980s, vertical integration, mostly under public ownership, was favoured for the power sector because it was considered a natural monopoly with sunk costs, inelastic demand and co-ordination problems in generation, transmission and distribution. After the rise of neo-liberal thinking, this model was criticised for its inefficiency and tendency to create excess capacity. It has been argued that the rationale for integrated power supply under public ownership has been weakened because of technological developments (Jamasb, et al 2005). For example, lower investment costs with combined cycle turbines increased new entries and developments in information technology improved co-ordination within different segments of the industry. In particular, the generation sector was highlighted for its potential to be competitive. 
The pioneers in privatisation and deregulation of the electricity sector have been the UK Chile and Argentina. The reform process was gradually standardised for application elsewhere. The prescription often involved unbundling of generation, transmission, wholesale and retail distribution with the introduction of some form of competition in all segments of the market except for transmission. The Appendix Table at the end of this article shows various aspects of power sector liberalisation for 42 countries from different regions in the world. Even though close to sixty per cent of countries included in this sample have adopted some form of unbundling in their electricity markets, only around one-third have opened their retail supply to competition. In other words, in most countries distribution is not separated from retail supply. Three quarters of countries with retail market competition achieved some level of supplier switching by consumers but mostly by large users. Belgium, Netherlands and the UK are the only countries with a significant level of switching by small users. Contradicting with this, however, is the extensive market concentration in most countries. More than three-quarters of countries for which data was available had their generation and supply markets controlled by three companies. Even higher levels of concentration prevail for the retail market.

Western European countries included in the Appendix Table are most advanced in opening up their electricity markets. Most of them have been deregulating their electricity industries to comply with the European Union Directives for liberalisation of energy markets since 1996. But deeper deregulation did not seem to have enhanced the competitive pressures as both the generation and supply markets are highly concentrated in many European countries. In South America, too, a considerable degree of opening is observed in generation. But for most other countries in the rest of the world market liberalisation has been limited with private entry into generation sector, especially, by independent power producers (IPPs).

While full market opening has been limited in many developing countries, most are resolved to continue with further deregulation to improve the performance in the power industry. What light does the extensive experience of some countries with the privatisation and liberalisation of power markets shed on the prospects for the followers? What lessons can developing countries learn from the West?

In Western Europe, the UK has one of most liberalised and competitive power market. It is entirely privatised with full retail market opening and considerable switching both by large and small users. In North America, the US has had comparable levels of power market deregulation in many of its states. ${ }^{1}$

The experience in the North especially in the US and the UK for over a decade points to the instability of 'the competitive model' in which prices are expected to equal the marginal cost of supply. Firstly, the evidence shows that an increase in the number of new entrants is neither a necessary nor a sufficient condition for competitive outcomes in a market with characteristics of the power sector. Prices reflecting marginal costs can be imposed in a heavily concentrated market. Similarly, prices can be far above the marginal cost of supply in a less concentrated private power industry. Sweeting (2007) demonstrates this in the case of the UK where wholesale electricity prices were close to the marginal cost of supply

\footnotetext{
${ }^{1}$ It is difficult to summarise the extent of deregulation for the US electricity markets as a whole in the Appendix Table as market structures vary greatly from one state to another. Aggregation in the presence of such differences is not possible.
} 
when the generation industry had a duopoly during 1995-1996, while they were above the marginal cost at a time when the market was much less concentrated following new entrants to the generation sector either because of the exercise of market power or collusion under capacity shortages.

Secondly, after the daunting failures in places like California, Alberta and Ontario during 2001-2003 (Woo et al. 2003) it is being increasingly recognised that privatised and deregulated power industries are more susceptible to failures if capacity constraints are pressing (Smith 2002, Borenstein 2002). In particular, the case of California, where the wholesale electricity prices more than quadrupled from 1999 to 2001, has been studied extensively. Use and abuse of market power is considerable in general but worse under capacity shortages (Jaskow 2001, Kelly 2003, Hansen 2005). These defects, if combined with tight input supply (e.g. low rainfall, fuel supply problems), fast growing demand and extreme weather during peak periods, can be a recipe for a catastrophe.

The most pressing problem is that 'the competitive model' failed in providing 'incentives' for investment in generation (Jaskow 2003, von Hirschhausen et al. 2004). There are two reasons for this. The first of these is related to the fact that customers can switch suppliers which create substantial investment risks and uncertainty for private investors. The second is related to a paradox of the 'competitive market' paradigm in that capacity shortages in the power sector push prices far above the marginal cost of supply while excess capacity lowers prices to levels that fall short of recovering investment costs (Lave et al. 2004, Reeder 2006). Hence, capacity shortage is desirable for the operators as it increases their profitability and power in the market but detrimental for consumers and the reliability of supply.

Reflections upon these failures in the developed world have led proponents to rethink the pre-conditions for privatisation and deregulation and to improve 'the market design'. Proposals have included making use of long term contracts (Jaskow 2003, Neuho and De Vries 2004) and capacity obligations or payments (Besser, et al. 2002, Stauffer 2006), introduction of 'real-time-pricing' (RTP) to achieve some responsiveness on the demand side to changing prices (Borenstein 2002, Kelly 2003), use of 'locational prices' for transmission (Green 2004, Turvey 2006) and changes in the mandate and responsibilities of the regulatory institutions (Newberry 2002).

Nevertheless, these solutions are not free from problems. Meters for RTP are costly, thus only worthwhile for large industrial power consumers. But because RTP requires more attention to risks (O'Sheasy, 2002) not many large consumers retain it (Barbose et al. 2006). Those remaining on RTP reduce their demand for power only when there are extraordinary increases in prices and by a small proportion (Hopper et al 2006). Locational pricing is considered as an ineffective exercise due its complexity and high start up costs (Kelly 2003). Use of long-term contracts and capacity payments are against the paradigm of 'competitive markets' as they would reduce the effectiveness of price signals in regulating demand and supply. The incentives for operators and retailers to engage in long-term contracts are limited, since end users can switch their suppliers (Roques et al. 2005).

As a consequence of the difficulty of recovering investment costs in the power sector the number of mergers has increased substantially over the last decade. Market concentration has increased in the European Union (EU 2004). This process has been particularly noteworthy in the UK since the New Electricity Trading Agreements (NETA) replaced 'the pool' (Newberry, 2004). The German power industry has become more 
concentrated following the liberalisation (Brunekreeft and Twelemann 2005). In the US, 56 mergers took place amongst power utilities between 1990 and 2000 (Moody 2004), and financial institutions seem to be 'urging' regulators not to prohibit takeovers of financially distressed generators to increase investments even if it comes at the cost of lower competition in the sector (Kelly and Moody 2005). In the developing world too, the unbundled power sectors are being re-integrated in some countries (Wamukonya 2003). In countries where there are many suppliers, a few dominate the market. In Chile, for example, three generators own 94 per cent of the installed capacity (del Sol 2002).

In sum, the evidence suggests that competition in the power sector has been impracticable with ambiguous long-term benefits in the advanced industrial economies. The integrated model under public or regulated private ownership in the North is now being praised for its reliable supply, low prices and universal access (Hunt 2002, Yi Chong 2005). Advocates are now more critical of the prospects after privatisation and deregulation.

"...there is as yet insufficient experience to assess the long-term benefits from liberalising the electricity industry. As the first countries to liberalise -among which are included Britain and some U.S. states- have now reached the end of their first investment cycle, much attention is being paid to assessing the long-term dynamic performance of the liberalised electricity industry" (Roques, et al. 2005, p. 122 )

Intuition would suggest that it must be harder for similar reforms to work well in developing economies. Indeed, the list of pre-conditions for the feasibility of privatisation and deregulation is longer for developing economies, including the need for sufficient production capacity, a viable network size, effective regulation, administrative capability and a strong institutional environment (Navarro and Shames 2003, Kessides 2004, Jamasb et al. 2005, Hansen 2005).

'In many LDCs, electrification is not complete... There is a system size below which vertical separation and competition is not effective or not worthwhile... Losses in the transmission and distribution networks are high. Non-payment is high. Capacity shortages, poor utilisation of existing capacity and unserved demand result in significant economic loss...Regulatory credibility, institutional weaknesses and political interference are more important drivers of private investment in the sector than in developed countries'. (Jamasb, et al. 2005)

By the time economists recognised the loopholes in neo-liberal power sector reforms, many developing countries in Asia, Africa and Latin America had already divested some of their existing plants and introduced private operators though independent power producers (IPPs). The IPPs have been trying to reduce their own risks in a number of ways at the cost of higher risks for governments and society at large.

In fact, most developing economies have not tried 'competition' or 'regulated competition' in power generation as in the US or the UK. Instead, the prospects for competition are circumvented from the beginning through the use of power purchase agreements (PPAs) between the governments and the IPPs, spanning 20-30 years, involving onerous conditions such as fixed prices, foreign currency indexing and 'take or pay' agreements. In Tanzania, for example, power sector reforms increased government transfers to the energy sector because of capacity and energy payment obligations to two major IPPs (Eberdhardt, et al 2005). For this or other reasons, contractual disputes and 
renegotiations are on the rise. In Latin America, for example, 21 per cent of all contracts in the power sector have been renegotiated on average within 2.1 years after being signed (Guasch, 2007).

Moreover, the fixation on privatisation has meant that large scale projects such as hydropower had to be abandoned in favour of the new technologies employed by IPPs, such as combined cycle turbines. Cheaper and cleaner generation with hydro plants are unattractive for private investors because recovering investment costs takes much longer and financing investments is more difficult. While start-up costs are lower with new technologies, the marginal cost of generation is often higher than conventional hydro units (Briscoe 1999, Wamukonya 2003). This is why in countries like Ghana tariffs increased steeply after the introduction of thermal generation with IPPs (Eberdhardt, et al 2005).

IPPs frequently finance their investments with loans from international markets but governments often act as full or partial guarantors for these loans and their obligations can be activated in times of crisis. Multilateral institutions provide loans to governments to pay for management fees or undertake investments and renovation before or after privatisation to attract private investors, etc. These practices raise concerns as to why the utility rents should be appropriated by private firms when risks are increasingly being shouldered by governments and tax payers.

The issues raised above have important implications for electricity prices and their affordability in the developing world. It is now clearer that policy makers in the developing world disregarded the importance of designing tariff structures for the affordability of services during the process of restructuring and privatisation (Estache 2006). For example, electricity tariffs were raised substantially following privatisation or restructuring in most African economies (Eberdthart et al, 2005). In some cases, tariff hikes were politically difficult to implement. In Argentina, wholesale electricity prices were halved but the cost of distribution increased, so households paid more for power (Haselip, 2005).

Figure 1. Real Electricity Prices in OECD and in the UK: 1978-2008

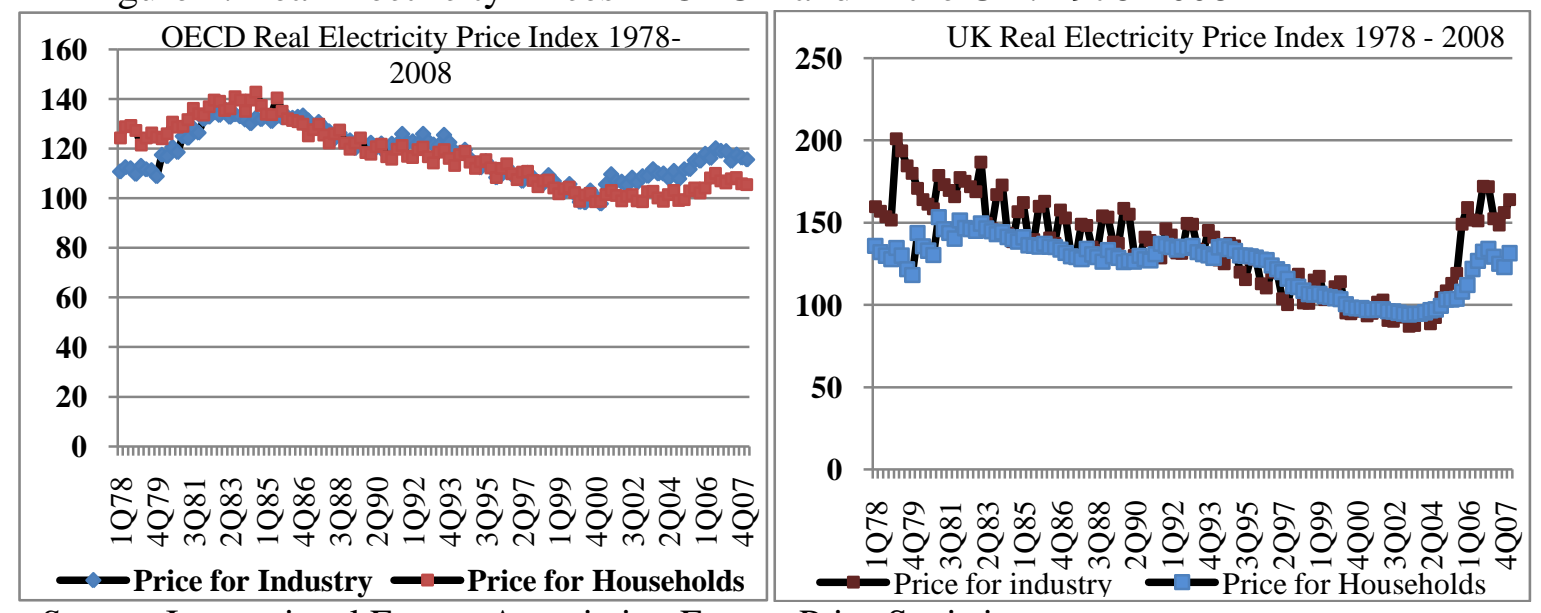

Source: International Energy Association Energy Price Statistics

In the North, prices declined initially but rose again later. In fact, as shown in Figure 1, real electricity prices in the OECD countries started declining from the mid 1980s onwards 
when the extent of power market deregulation was limited. After 2000, when some market opening was already underway prices started to increase.

In the UK, prices were on a declining trend from the early 1980s onwards, a decade before privatisation and liberalisation. This trend was maintained after privatisation and deregulation in the 1990s as a result of restructuring, new investments that generated 'dash for cheaper gas' and price-cap regulation (Pollitt 2005). Recently, though, they have been on the rise because of the downturn in investments, increasing fuel prices, lack of diversification in generation (rising dependence on gas) and higher emission charges. In the US, deregulation has had no affect on power prices in the long-term except for some mandated cuts in domestic tariffs (Lave et al. 2004). Therefore, short-term results can be misleading. What matters is the sustainability of affordable prices for essential services in the long term.

\section{Effectiveness of Regulation}

Mainstream economic theory suggests public ownership for natural monopolies and for firms that produce goods and services with externalities or public good characteristics in order to tackle market failures. The advent of property rights and public choice theories swung the pendulum in favour of private ownership by underlining government failures such as rent-seeking and lack of incentives for innovation. Regulation is seen as a remedy for market failures in non-competitive sectors. ${ }^{2}$

This rhetoric has increasingly been influential. Many countries in both the developed and developing world have now have a regulatory establishment, overseeing the power sector developments as shown in the Appendix Table at the end of this paper. Overall, what it shows is that regulatory map of the world varies enormously. Most countries have a regulatory body in the power sector, two-third of them with jurisdical independence. However, this basic categorisation hides many complexities in the process of regulation.

In some countries one regulatory institution is responsible for other utilities such as gas, water and telecom as well as electricity (e.g. Belgium, Germany, Colombia, Ghana) while in others there is a unique regulatory set up for power sector alone (e.g. the UK, France, Portugal, India, Pakistan, Argentina, Kenya, South Africa). The mandate of the regulators differs considerably from country to country, too. In some, they might be responsible for a small range of activities such as price regulation as in Kenya, while in others they might have wider responsibilities such as policy making in the electricity industry, including the design of market structure and implementation of deregulation process as in Germany, the UK, Argentina, Chile, South Africa. Similarly, while a considerable number of regulatory bodies are established as 'independent' institutions, the degree of independence in practice varies considerably. In many countries, regulators either face direct interventions by the government on an ad hoc basis or continually operate under the influence of governments despite their legally independent status. Dubash and Rao (2008), for example, describe the circumstances in this respect for India. Similar views are expressed for Kenya (ABS, 2006) and Ghana (Bayliss and Fine, 2007).

\footnotetext{
${ }^{2}$ See, Florio (2006) for an in depth discussion of the evolution of the theoretical perspectives on ownership and company performance.
} 
Neither are the details outlined above sufficient for the assessment of regulatory effectiveness in general or in specific circumstances. Three issues are crucial for the effectiveness of regulation. The first is the regulatory capacity which is contingent upon the powers assigned and resources available to the regulatory institution (including funding, education, skills and experience of personnel such as accountants, lawyers, inspectors, engineers with good remuneration).

The second is the institutional environment in which regulators operate. The existence of regulatory institutions with appropriate tools, powers and capacity is not sufficient. Outside the regulatory bodies, culture, politics and social context play a significant role in general and in the nature of 'commitments' and 'credibilities' of the contracting parties in particular. The legal system, dispute settlement mechanisms, efficient administration of regulatory matters by public institutions, corruption and bankruptcy procedures are some other factors that influence the effectiveness of regulation.

The third is the possibility of regulatory capture through which private interest groups influence the way the regulatory process is designed and implemented so as to appropriate utility rents to the detriment of 'the public interest' with socially non-optimal outcomes (Stigler 1971).

The evidence shows that the degree of regulatory effectiveness varies from country to country. Generally, however, serious weaknesses are identified in the regulatory objectives, processes, capacity and institutional environment in developing countries (Bell 2003, Parker and Kirkpatrick 2004, Minogue and Cariño 2006). There are cases in which utility privatisations have been carried out without a regulatory institution or with one functioning as window display. There are also concerns that social stratification involving clan systems, tribal divisions and other forms of relationship contracting in developing world can reinforce 'regulatory capture' (Parker and Kirkpatrick 2004).

While it is possible for developing economies to build an effective regulatory system and capacity over time, the nature of this development process is very much a 'black box' in the development literature on the privatisation of utilities. The dynamic aspects of regulatory effectiveness are ignored. Capacity development perceived as a mechanical process as if it is a matter of adapting the 'best' regulatory tools -often developed elsewhere- and as if there is an ultimate ideal regulatory entity that needs to be built to tackle the market failures. For example Cubbin and Stern (2006) suggest that it takes on average 14 years to build up a regulatory capacity with maximum impact. The data in the Appendix Table suggest that that two-thirds of the countries considered have had 10 years or less experience with the regulation of electricity markets. Out of 38 countries for which data was available, only five countries have had 14 years or more practice in power sector regulation.

Moreover, the performance of regulatory entities is often 'second best' even in pioneer countries like the US and the UK with long years of know-how in the sector. They learn their 'trade' along the way. Responses to emerging problems are hardly ever simultaneous. Improvements on one front reveal weaknesses on other fronts.

For example, most regulators have used 'cost-plus' (or rate of return) regulation in the early years which led to over investment and revealed considerable inefficiencies in containing costs (Berg and Lin 2005, Menard and Clarke 2002a). As a result, there has been a shift towards 'price-cap' regulation (Politt 2005), which is about to be discarded in favour of more 'hybrid regimes' (Estache et al 2005) because of its disincentive effects for 
investment. The financial crises in Asia and Argentina revealed other contingencies such as indebtedness of companies which can also become subject to regulation (Corria da Silva, et al. 2006).

Regulatory inefficiencies have distributional consequences. Intertemporal loopholes until the regulators take corrective measures create winners and losers. For example, gains after privatisation have either been captured by companies or the government in Argentina because regulator's price caps initially underestimated the cost savings. In the UK, the benefits of higher productivity in infrastructure were not always shared with consumers (Price and Young 2003).

Overall, as pointed out by von Hirschhausen et al. (2004) 'regulation is a repeated game between the regulator and the regulated enterprise'. The outcomes of this game are dependent upon myriad number of economic, social, political and technical factors. The time lags in the responsiveness of regulators can have significant social costs, which in the case of developing countries are likely to be substantial. Other development goals such as industrialisation depends on energy policies and hence independent regulation of electricity industry may present some incongruence in some cases which may lead to circumstances in which regulators are undermined by political processes or broader development goals are sacrificed for the principle of regulatory independence.

From, a theoretical point of view, the agency theory (Sappington and Stiglitz 1987) and incomplete contracts framework (Hart et al. 1997, Hart 2003, Martimort 2006) made important contributions, which are particularly relevant for the debate on utility privatisations. A balanced interpretation of these perspectives indicates that there is no prima facie case for the superiority of one form of ownership over the other. Rather, the outcomes of privatisation are contingent upon various other factors (e.g. sector specific factors, competing objectives, information asymmetries between different agents, the hazards of contract incompleteness and incentives under different ownership).

The problems associated with asymmetric information and incompleteness of contracts between different agents (especially the state, regulators and private operators) are inherent in most private utilities, including electricity. These cannot be entirely and permanently solved by regulation or other corrective policy measures. For example, in the power sector, regulators could not distinguish between the exercise of market power and scarcity rent (Fraser, 2003) when price hikes are allowed to signal capacity shortages. Legal battles and renegotiations with private electricity companies highlight the dangers associated with 'contract incompleteness' in utility concessions. Various factors are considered in the literature for the renegotiation of concession contracts in the utilities. For example, high transaction costs in contracting out services on a long term basis ( $\mathrm{Ng}$ and Loosemore 2007) act as deterrents for governments to cancel contracts in case of contractual disputes. This is a source of opportunism for operators in that they can place the most attractive bid and request renegotiation after contracts are signed. These costs may multiply several times in cases where renegotiation of contracts takes place due to the contingencies over the life of the contract. Opportunism by governments or firms (Parker and Kirkpatrick 2004), manipulation by private companies, external shocks, underestimation of the costs of business (Bell 2003), weaknesses in contract design, quality of administration and regulation and elections (Guasch et al. 2006) are also mentioned in the literature.

Such disputes and renegotiations have been common in the developing world. For example, following the crisis in Argentina and abandonment of the US dollar denominated 
and indexed tariffs, 62 public services contracts went to the World Bank's International Centre for the Settlement of Investment Disputes and close to half of them have been in the power sector (Haselip 2005). In Maharashtra (India), a new government reviewed the contract with Dabhol power company and decided that it favoured the interest of the private company over those of the people. As a result of non-payment by the State Electricity Board a legal battle started (Parker and Kirkpatrick 2004). In Latin America, more than half of the concession contracts during 1988-2004 involving the private sector in infrastructure have been renegotiated in less than two years after the contracts were signed (Guasch et al. 2006 and Guasch 2007).

Finally, while the 'agency theory' and 'incomplete contracts framework' are highly relevant for the analysis of regulatory effectiveness they have several weaknesses. They are based on a relatively simple agency framework, often with one principal and one agent. In reality, agency composition in the delivery of services like water and electricity is much more complex with multiple principals and agents, each with potentially different objectives and interests (e.g. ministers as agents of electors but principals as service providers, the poor as consumers and voters, regulators as agents of governments, foreign and local managers of private companies with mixed ownership, company shareholders). Moreover, both of these approaches focus on the microeconomic aspects of ownership changes, especially on the performance of companies like other theories (e.g. public choice, property rights) and have very little to say on the political economy aspects of utility privatisation, including inequality, poverty, affordability and the lack of access to services, which are pressing problems in the developing world. Of particular relevance for developing economies is the role of regulation in poverty alleviation which has not been discussed in detail so far as pointed out by Figueira-Theodorakopoulou et al. (2007). On the whole, the tension after privatisation between profit maximisation and extension of services, or the affordability of services, is not only an economic one but also a political one.

\section{Conclusions}

This paper provides a review of developments in the privatisation of electricity industry and questions the superiority of the 'private model' for developing countries. It shows that the theoretical and empirical validity of the assertion that privatisation enhances competition and hence efficiency remains dubious. Competition in the electricity sector has remained highly imperfect even in the segments of the market where it has been considered feasible. Problems of market power have been identified in countries such as the UK and the US, which are most advanced in the implementation of power sector reforms. Market concentration has been increasing in the sector. The goal of efficient supply with affordable services and reasonable profits has been threatened by the difficulty of providing optimal incentives for investment in the sector. In the developing world, competition has been impracticable from the start through the use of power purchasing agreements. Increasingly, the public sector is involved in private projects to undertake or share the risks that the private sector is unwilling to take on.

It also argues that the emphasis in the recent literature on regulation as 'the cure' for market failures after privatisation is problematic in some respects. Regulatory effectiveness, however defined, requires regulatory capacity, which continues to evolve even in the developed countries and remains far from 'the ideal'. In the presence of information 
asymmetries, incomplete contracts and future uncertainties, our perception of what that ideal may be is vague. The response to emerging problems is piecemeal, partial and not simultaneous. Developing regulatory capacity in the South with a mechanistic view of institutional and procedural replication is fraught with difficulties. Regulatory weaknesses, whether structural or transitory, have distributional consequences.

\section{Bibliography}

ABS (2006) Electricity Deregulation Report - Global 2006, London: ABS Energy Research

BARBOSE G, GOLDMAN C and NEENAN B. 2006. 'The role of demand response in default service pricing' The Electricity Journal, 19 (3): 64-74

BAYLISS K and FINE B. (2007) Privatization and Alternative Public Sector Reform in Sub-Saharan Africa: Delivering on Electricity and Water, London, Palgrave Macmillan

BELL M. 2003. 'Regulation in developing countries is different: Avoiding negotiation, renegotiation and frustration' Energy Policy, 31 (4): 299-305

BERG S and LIN C. 2005. 'Regulation of state-owned and privatized utilities: Ukraine electricity distribution company performance' Journal of Regulatory Economics, 28 (3): 259-287

BESSER J G, FARR J G and TIERNEY S F. 2002. 'The political economy of long-term generation adequacy: Why an ICAP mechanism is needed as part of standard market design' The Electricity Journal, 15 (7): 53-62

BORENSTEIN, S. 2002. 'The trouble with electricity markets: Understanding California's restructuring disaster' Journal of Economic Perspectives, 16 (1): 191-211

BORTOLOTTI B and PEROTTI E. 2007. 'From government to regulatory governance: Privatisation and the residual role of the state' The World Bank Research Observer, 22 (1): 53-66

BRISCOE J. 1999. 'The financing of hydropower, irrigation and water supply infrastructure in developing countries' Water Resources Development, 15(4): 459-91

BRUNEKREEFT G and TWELEMANN S. 2005. 'Regulation, competition and investment in the German electricity market: RegTP or REGTP' Energy Journal, 26: 99-126

CORRIA da SILVA L, ESTACHE A and JARVELA S. 2006. 'Is debt replacing equity in regulated privatised infrastructure in LDCs?' Utilities Policy, 14 (2): 90-102

CUBBIN J and STERN J. 2006. 'The impact of regulatory governance and privatization on electricity industry generation capacity in developing economies' The World Bank Economic Review, 20 (1): 115-141

del SOL, P. 2002. 'Responses to electricity liberalization: the regional strategy of a Chilean generator' Energy Policy, 30: 437-446

DUBASH N. K. and RAO, D. N (2008) 'Regulatory practice and politics: Lessons from independent regulation in Indian electricity’ Utilities Policy, pp. 1-11

EBERHARDT A, CLARK A, WAMUKONYA N and GRATWICK K. 2005. Power Sector Reform in Africa: Assessing Impact on Poor People. World Bank Energy Sector Management Assistance Programme. No. 306/05,

ESTACHE A. 2006. 'PPI Partnerships vs. PPI Divorces in LDCs' Review of Industrial Organization. 29: 3-26 
ESTACHE A, PERELMAN S and TRUJILLO L. 2005. 'Infrastructure performance and reform in developing and transition economies: evidence from a survey of productivity measures' World Bank Policy Research Working Paper 3514

E. U. 2004. 'Horizontal evaluation of the performance of network industries providing services of general economic interest' Commission Staff Working Paper SEC 866

FIGUEIRA-THEODORAKOPOULOU C, PARKER D and KIRKPATRICK C. 2007. 'Infrastructure regulation and poverty reduction in developing countries: A review of the evidence and a research agenda' The Quarterly Review of Economics and Finance - in press

FRASER P. 2003. 'Power generation investment in electricity markets', OECD/IEA

FLORIO M. 2006. 'Privatisation theories and cost-benefit analysis' The Great Divestiture. The MIT Press

GREEN R. 2004. 'Electricity transmission pricing: how much does it cost to get it wrong?' Cambridge Working Papers in Economics

GUASCH J. L. 2007. 'Renegotiating and renegotiating infrastructure PPPs and concessions: key issues for policy makers. Paper submitted to International Seminar on Strengthening Public Investment and Managing Fiscal Risks from PPPs' Budapest, Hungary March 7-8

GUASCH J. L, LAFFONT J. J. and STRAUB S. 2006 'Renegotiation of concession contracts: a theoretical approach' Review of Industrial Organization. 29: 55-73

HANSEN C. J. 2005. 'Electricity reform in developing countries: continued momentum' Journal of Energy Literature, 11(1): 21-39

HART O, SHLEIFER A and VISHNY R W. 1997 'The Proper Scope of Government: Theory and an Application to Prisons' Quarterly Journal of Economics, 112 (4): 11271161.

HART O. 2003. 'Incomplete contracts and public ownership: remarks and an application to public-private partnerships’ Economic Journal, 113: C69-C76.

HASELIP J. 2005. 'Renegotiating electricity contracts after an economic crisis and currency devaluation: the case of Argentina' The Electricity Journal, 18 (3): 78-88

HOPPER N, GOLDMAN C and NEENAN B. 2006. 'Demand response from day-ahead hourly pricing for large customers' The Electricity Journal, 19 (3): 52-63

HUNT S. 2002. 'The state of U.S. electricity restructuring' The Electricity Journal, 15 (5): 11-19

JAMASB T, MOTA R, NEWBERY D and POLLITT M. 2005. 'Electricity sector reform in developing countries: a survey of empirical evidence on determinants and performance' World Bank Policy Research Working Paper 3549

JOSKOW P L. 2001. 'California's electricity crisis' Oxford Review of Economic Policy, 17 (3): 365-388

JOSKOW P. L. 2003. 'Electricity sector restructuring and competition: lessons learned' Cuadernos de Economía, 40 (121): 548-558

KELLY J. 2003. 'The missing manifesto: what economists should be saying about electric utility restructuring in the United States' The Electricity Journal, 16 (1): 13-24

KELLY S and MOODY D. 2005. 'Wholesale electric restructuring: Was 2004 the tipping point?' The Electricity Journal, 18 (2): 11-18

KESSIDES I. N. 2004) Reforming Infrastructure: Privatization, Regulation, and Competition, A co-publication of the World Bank and Oxford University Press 
LAVE L B, APT J and BLUMSACK S. 2004. 'Rethinking electricity deregulation' The Electricity Journal. 17 (8): 11-26

MARTIMORT D. 2006. 'An agency perspective on the costs and benefits of privatization' Journal of Regulatory Economics, 30: 5-44

MINOGUE M and CARIÑO L. eds. 2006. Regulatory Governance in Developing Countries. Cheltenham, Edward Elgar

MOODY D. C. 2004. 'Ten years of experience with deregulating US power markets' Utilities Policy, 12: 127-137

NAVARRO P. and SHAMES M. 2003. 'Aftershocks -and essential lessons- from the California electricity debacle’ The Electricity Journal. 16 (4): 24-30

NELLIS J. 2003. 'Privatization in Africa: What has happened? What is to be done?' Center for Global Development Working Paper No. 25

NEUHO K and De VRIES L. 2004. 'Insufficient incentives for investment in electricity generations' Utilities Policy, 12: 253-267

NEWBERY D. M. 2004. 'Regulation and competition policy: longer-term boundaries' Utilities Policy, 12: 93-95

NEWBERY D. M. 2002. 'Problems of liberalizing the electricity industry' European Economic Review, 46: 919 - 927

NG A. and LOOSEMORE M. 2007. 'Risk allocation in the private provision of public infrastructure' International Journal of Project Management, 25 (1): 66-76.

O'SHEASY M. T. 2002. 'Is real-time pricing a panacea? If so, why isn't it more widespread?' The Electricity Journal, 15 (10): 24-34

PARKER P and KIRKPATRICK C. 2004. 'Economic regulation in developing countries: A framework for critical analysis' Leading Issues in Competition, Regulation and Development. P. Cook, C. Kirkpatrick, M. Minogue and D. Parker, eds. Cheltenham, Edward Elgar

POLLITT M. 2005. 'The role of efficiency estimates in regulatory price reviews: Ofgem's approach to benchmarking electricity networks' Utilities Policy, 13 (4): 279-288

PRICE C W and YOUNG A. 2003. 'UK Utility reforms: distributional, implications and government response' Utility Privatization and Regulation, C Ugaz and C Waddams Price, eds. Cheltenham, Edward Elgar, pp. 101-124

REEDER M. 2006. 'Want to put an end to capacity markets? Think real-time pricing' The Electricity Journal, 19 (6): 38-48

ROQUES F A, NEWBERY D M and NUTTALL J W. 2005. 'Investment incentives and electricity market design: the British Experience' Review of Network Economics, 14 (2): 94-128

SAPPINGTON D. E. M. and STIGLITZ J E. 1987. 'Privatization, Information and Incentives' Journal of Policy Analysis and Management, 6 (4): 567-82.

SMITH M D. 2002. 'Lessons to be learned from California and Enron for restructuring electricity markets' The Electricity Journal, 15 (7): 23-32

STAUFFER H. 2006. 'Capacity markets and market stability' The Electricity Journal, 19 (3): $75-80$

STIGLER G. J. 1971. 'The theory of economic regulation' Bell Journal of Economics and Management Science, 2 (1): 3-21

SWEETING A. 2007. Market power in the England and Wales wholesale electricity market 1995-2000' The Economic Journal, 117: 654-685 
TURVEY R. 2006. 'Short \& long run transmission incentives for generation location' Centre for Energy and Environmental Policy Research

von HIRSCHHAUSEN C, BECKERS T and BRENCK A. 2004. 'Infrastructure regulation and investment for the long-term — an introduction' Utilities Policy, 12: 203-210

WAMUKONYA N. 2003. 'Power sector reform in developing countries: mismatched agendas' Energy Policy. 31: 1273-1289

WOO C-K, LLOYD D and TISHLER A. 2003. 'Electricity market reform failures: UK, Norway, Alberta and California' Energy Policy, 3(1): 1103-1115

YI-CHONG X. 2005. Models, templates and currents: the World Bank and electricity reform' Review of International Political Economy, 12 (4): 647-673 
Appendix Table - The Extent of Liberalisation in the World Electricity Markets - Selected Countries

\begin{tabular}{|c|c|c|c|c|c|c|c|c|c|c|c|c|c|c|c|}
\hline & \multirow[b]{2}{*}{$\left|\begin{array}{c}\text { Unbun } \\
\text { dled? }\end{array}\right|$} & \multirow{2}{*}{$\begin{array}{l}\text { Years since } \\
\text { private } \\
\text { ownership } \\
\text { started (max } \\
\text { 20) }\end{array}$} & \multirow{2}{*}{$\left|\begin{array}{c}\% \text { of } \\
\text { market } \\
\text { open } \\
2006\end{array}\right|$} & \multirow{2}{*}{$\begin{array}{c}\text { years } \\
\text { since } \\
\text { first } \\
\text { retail } \\
\text { market } \\
\text { opening }\end{array}$} & \multicolumn{2}{|c|}{$\begin{array}{c}\% \text { of Switching } \\
\text { since market } \\
\text { opening }\end{array}$} & \multirow{2}{*}{$\begin{array}{c}\text { \% Share } \\
\text { of top } 3 \\
\text { Gs by } \\
\text { capacity }\end{array}$} & \multirow[b]{2}{*}{$\begin{array}{l}\text { No } \\
\text { of } \\
\text { Ts }\end{array}$} & \multirow[b]{2}{*}{$\begin{array}{l}\text { No of } \\
\text { DNOs }\end{array}$} & \multirow[b]{2}{*}{$\begin{array}{c}\text { No of } \\
\text { indepen } \\
\text { dent Ss }\end{array}$} & \multirow[b]{2}{*}{$\begin{array}{l}\text { No } \\
\text { of } \\
\text { Ss }\end{array}$} & \multirow[b]{2}{*}{$\begin{array}{l}\text { Top } 3 \\
\text { Ss } \\
\text { Share }\end{array}$} & \multirow[b]{2}{*}{\begin{tabular}{|c}
$\mathrm{R}$ \\
exists?
\end{tabular}} & \multirow[b]{2}{*}{$\begin{array}{c}\mathrm{R} \\
\text { indepen } \\
\text { dent? }\end{array}$} & \multirow[b]{2}{*}{$\begin{array}{c}\text { Years } \\
\mathrm{R} \\
\text { exists }\end{array}$} \\
\hline & & & & & $\begin{array}{l}\text { large } \\
\text { users }\end{array}$ & $\begin{array}{l}\text { small } \\
\text { users }\end{array}$ & & & & & & & & & \\
\hline \multicolumn{16}{|c|}{ WESTERN EUROPE } \\
\hline Austria & yes & 20 & 100 & 5 & 22 & 3 & 75 & 3 & 133 & 19 & 144 & $67 \%$ & yes & yes & 7 \\
\hline Belgium & yes & 20 & 90 & 5 & 35 & 19 & 95 & 1 & 27 & 17 & 41 & $90 \%$ & yes & yes & 8 \\
\hline France & yes & 3 & 70 & 6 & 22 & 0 & 95 & 1 & 166 & 15 & 25 & 88 & yes & yes & 8 \\
\hline Germany & yes & 20 & 100 & 8 & 35 & 6 & 75 & 4 & 950 & 100 & 1050 & 50 & yes & yes & 3 \\
\hline Greece & yes & 10 & 62 & 1 & 0 & 0 & 100 & 1 & 1 & 9 & 10 & 100 & yes & yes & 8 \\
\hline Ireland & yes & 16 & 100 & 6 & 50 & 1 & 90 & 1 & 1 & 7 & 9 & 88 & yes & yes & 9 \\
\hline Italy & yes & 9 & 79 & 7 & 15 & 0 & 75 & 1 & 170 & 270 & 305 & 35 & yes & yes & 11 \\
\hline Luxembourg & no & 20 & 84 & 5 & 10 & 0 & 100 & 2 & 11 & 1 & 12 & 100 & yes & yes & 8 \\
\hline Netherlands & yes & 4 & 100 & 7 & 30 & 35 & 80 & 1 & 20 & 16 & 37 & 88 & yes & yes & 8 \\
\hline Portugal & yes & 10 & 100 & 6 & 9 & 1 & 80 & 1 & 11 & 3 & 4 & 99 & yes & yes & 13 \\
\hline Spain & yes & 20 & 100 & 6 & 18 & 0 & 80 & 1 & 308 & 62 & 70 & 85 & yes & yes & 8 \\
\hline Switzerland & no & 20 & 0 & 0 & 0 & 0 & 60 & 7 & 800 & 0 & 800 & 38 & no & no & 0 \\
\hline UK & yes & 19 & 100 & 18 & 50 & 50 & 40 & 2 & 15 & 66 & 80 & 79 & yes & yes & 19 \\
\hline \multicolumn{16}{|l|}{ ASIA } \\
\hline Japan & no & 4 & 63 & 2 & 0 & 0 & 59 & 10 & 10 & 0 & 10 & - & no & no & 0 \\
\hline South Korea & no & 0 & 0 & 0 & 0 & 0 & 100 & 1 & - & - & - & - & no & no & 0 \\
\hline China, PRC & no & IPPs & 0 & 0 & 0 & 0 & - & 2 & $100 \mathrm{~s}$ & 0 & $100 \mathrm{~s}$ & 0 & yes & no & 5 \\
\hline Indonesia & no & 13, Incl. IPPs & 0 & 0 & 0 & 0 & 52 & 1 & $2-4$ & 0 & $2-4$ & 100 & yes & - & - \\
\hline Malaysia & no & 9, Incl. IPPs & 0 & 0 & 0 & 0 & 60 & 1 & 3 & 0 & 3 & 100 & yes & yes & 7 \\
\hline India & yes & 6 & 0 & 0 & 0 & 0 & 30 & 1 & 25 & 0 & 25 & - & yes & yes & 10 \\
\hline Pakistan & no & All IPPs & 0 & 0 & 0 & 0 & 100 & 1 & 9 & 0 & 9 & - & yes & yes & 11 \\
\hline
\end{tabular}




\begin{tabular}{|c|c|c|c|c|c|c|c|c|c|c|c|c|c|c|c|}
\hline & $\left|\begin{array}{c}\text { Unbun } \\
\text { dled? }\end{array}\right|$ & \begin{tabular}{|} 
Years since \\
private \\
ownership \\
started (max \\
20)
\end{tabular} & $\left|\begin{array}{c}\% \text { of } \\
\text { market } \\
\text { open } \\
2006\end{array}\right|$ & $\begin{array}{c}\text { years } \\
\text { since } \\
\text { first } \\
\text { retail } \\
\text { market } \\
\text { opening }\end{array}$ & \multicolumn{2}{|c|}{$\begin{array}{l}\% \text { of Switching } \\
\text { since market } \\
\text { opening }\end{array}$} & $\begin{array}{l}\% \text { Share } \\
\text { of top } 3 \\
\text { Gs by } \\
\text { capacity }\end{array}$ & $\begin{array}{l}\text { No } \\
\text { of } \\
\text { Ts } \\
\end{array}$ & $\begin{array}{l}\text { No of } \\
\text { DNOs }\end{array}$ & $\begin{array}{c}\text { No of } \\
\text { indepen } \\
\text { dent Ss }\end{array}$ & $\begin{array}{l}\text { No } \\
\text { of } \\
\text { Ss }\end{array}$ & $\begin{array}{l}\text { Top } 3 \\
\text { Ss } \\
\text { Share }\end{array}$ & \begin{tabular}{|c}
$\mathrm{R}$ \\
exists?
\end{tabular} & $\begin{array}{c}\mathrm{R} \\
\text { indepen } \\
\text { dent? }\end{array}$ & $\begin{array}{c}\text { Years } \\
\mathrm{R} \\
\text { exists }\end{array}$ \\
\hline \multicolumn{16}{|c|}{ SOUTH AMERICA } \\
\hline Argentina & yes & 16 & 100 & 14 & 0 & 0 & 30 & 7 & 28 & 0 & 28 & - & yes & yes & 15 \\
\hline Bolivia & yes & 14 & - & 0 & 0 & 0 & 58 & 3 & 6 & 0 & 6 & - & yes & yes & 14 \\
\hline Brazil & yes & - & 0 & 0 & 0 & 0 & - & 1 & 64 & 0 & 64 & - & yes & semi & 12 \\
\hline Chile & yes & 20 & 100 & - & 0 & 0 & 70 & 4 & 20 & 0 & 20 & - & yes & yes & 26 \\
\hline Peru & yes & 12 & 45 & 10 & 0 & 0 & 35 & 1 & 12 & 0 & 12 & - & yes & yes & 14 \\
\hline Venezuela & no & 0 & 0 & 0 & 0 & 0 & 94 & 1 & - & 0 & - & 73 & yes & no & 20 \\
\hline Mexico & no & 7 yr, most IPPs & 0 & 0 & 0 & 0 & 98 & 1 & 13 & 0 & 13 & - & yes & no & - \\
\hline \multicolumn{16}{|l|}{ AFRICA } \\
\hline Ethiopia & no & all IPPs & 0 & 0 & 0 & 0 & 100 & 1 & 1 & 0 & 1 & 100 & no & no & 0 \\
\hline Kenya & yes & all IPPs & 0 & 0 & 0 & 0 & 92 & 1 & 1 & 0 & 1 & 100 & yes & yes & 8 \\
\hline Tanzania & yes & IPPs & 0 & 0 & 0 & 0 & - & 1 & 1 & 0 & 1 & 100 & no & no & 0 \\
\hline Uganda & yes & $6 \mathrm{yr}$, incl.IPPs & 0 & 0 & 0 & 0 & - & 1 & 1 & 0 & 1 & 100 & yes & semi & 8 \\
\hline Ghana & yes & all IPPs & 0 & 0 & 0 & 0 & - & 1 & 2 & 0 & 2 & 100 & yes & yes & 11 \\
\hline Nigeria & yes & all IPPs & 0 & 0 & 0 & 0 & - & - & - & - & - & - & yes & yes & 3 \\
\hline South Africa & yes & all IPPs & 0 & 0 & 0 & 0 & $>95$ & 1 & 191 & 0 & 191 & $>50$ & yes & yes & 13 \\
\hline Namibia & yes & 8 & 0 & 0 & 0 & 0 & 100 & 1 & 5 & 0 & 1 & 100 & yes & semi & 7 \\
\hline Zambia & no & 8 & 0 & 0 & 0 & 0 & 100 & 1 & 1 & 0 & 1 & 100 & yes & semi & 13 \\
\hline \multicolumn{16}{|c|}{ MIDDLE EAST } \\
\hline Egypt & no & all IPPs & 0 & 0 & 0 & 0 & 100 & 1 & 8 & 0 & 8 & - & yes & yes & 8 \\
\hline Israel & no & 0 & 0 & 0 & 0 & 0 & 100 & 1 & 1 & 0 & 1 & 100 & yes & - & - \\
\hline Qatar & no & 4 yr, all IPPs & 0 & 0 & 0 & 0 & 100 & 1 & 1 & 0 & 1 & 100 & no & no & 0 \\
\hline Saudi Arabia & no & 0 & 0 & 0 & 0 & 0 & 94 & 1 & 1 & 0 & 1 & 100 & yes & yes & 7 \\
\hline Morocco & no & all IPPs & 0 & 0 & 0 & 0 & 100 & 1 & 15 & 0 & 15 & - & no & no & 0 \\
\hline Turkey & yes & 3 & 0 & 0 & 0 & 0 & $>95$ & 1 & 9 & 0 & 9 & 100 & yes & yes & 7 \\
\hline
\end{tabular}

Source: ABS (2006)

Gs= Generating companies, DNOs: Distribution Network Operators, Ss: Supplier companies,

R: Regulator,
Ts: Companies in Transmission, 